\title{
Use of Generational Theory for the Assessment of Involvement In International Electronic Commerce Activities
}

\author{
Guoda ČERNIAUSKAITE் ${ }^{1}$, Jolanta SABAITYTÉ ${ }^{2}$, Edita LEONAVIČIENE் $\dot{ }^{3}$ \\ ${ }^{1,3}$ Vilnius Gediminas Technical University, Faculty of Business Management, Department of Business Technology and \\ Entrepreneurship, Sauletekio al. 11, LT10223 Vilnius, Lietuva \\ ${ }^{2}$ General Jonas Žemaitis Military Academy of Lithuania, Department of Defence Technologies, Silo str. 5 a, LT10322 \\ Vilnius, Lietuva
}

E-mails: ${ }^{1}$ guoda.cerniauskaite@stud.vgtu.lt; ${ }^{2}$ jolanta.sabaityte@gmail.com; ${ }^{3}$ edita.leonaviciene@vgtu.lt

\begin{abstract}
Over the past two decades the number of Internet users around the world has incredibly increased. E-commerce is becoming a potential area for business development creating significant added value for the global economy. This increases competition between e-commerce platforms and makes it difficult to survive. The purpose of this article is to create a conceptual model for the success of e-commerce by identifying the factors that determine the involvement of different generations in the international e-commerce activities. An analysis of the scientific literature was carried out to identify the factors. The assessment of existing success factors and success models has identified weaknesses and shaped the model of e-commerce success, which includes the generational divide as a factor that determines the choice of the consumer.
\end{abstract}

KEY WORDS: Information technology, e-commerce, e-commerce project, e-commerce success model, success factors

\section{Introduction}

The development of rapidly evolving information and communication technologies has led to changes in the world of traditional business. Mobile data technology has led to the active development of electron business. (Cristofaro, 2019). The Internet and information technology revolution has created the conditions for companies to create new structures that connect businesses with consumers, suppliers and other public institutions. According to data from the Global Internet Statistics (Miniwatss marketing group, 2019), the number of Internet users has increased by $1156.64 \%$ over the last 19 years. According to data from the global digital revolution (Kinda, 2019), the leading state in terms of the number of e-business platforms is China. Since the emergence of e-commerce, China's share of e-commerce in the global value of e-commerce retail transactions has increased from less than $1 \%$ to more than $50 \%$. Global e-commerce turnover, including e-services, was $\$ 3.53$ trillion worldwide in 2019 and is projected to grow to $\$ 6.54$ trillion by 2022 (Clement, 2019). The analysis of statistics shows that e-commerce is growing and adding value for the global economy. However, competition is also growing as the potential for e-commerce grows. It is claimed that $90 \%$ of e-business start-ups fail in the first 120 days of realization, while the remaining $10 \%$ manage to build a successful e-commerce business (Rigby, 2019). A low percentage is determined by important factors such as: knowledge and competence of the manager, choice of suitable manufacturers, brand awareness, system efficiency and security, existing market analyses and continuous knowledge gathering and development (Choshin, 2017; Wang et al., 2019, Dasuki, 2018; Prakapiene etl. al. 2018). When examining scientific literature, it can be noted that the success of e-commerce can be determined by a number of mutually correlated factors (Abdullah et al., 2019). Some scientists analyse the success factors of e-commerce based on the model of success of The Delone and McLean information systems (Roky ir Meriouh, 2015; Delone ir McLean, 2003; Wang et al., 2019; Dasuki, 2018). These researchers highlight eight key factors: system quality, information novelty, quality of service, system usage frequency, usage targets, user satisfaction, individual impact and organizational impact. Meanwhile, other researchers place greater emphasis on the quality of logistics services, the quality of the web page, functionality, security and reliability (Abdullah et al., 2019; Jagannathan et al., 2018, and Lin, 2016). However, it should be noted that there is a lack of information in analyzing the needs of users of different generations and the decisions they make, during shopping, on e-commerce platforms. The purpose of this article is to establish a conceptual model of factors that determine the

\footnotetext{
${ }^{1}$ Corresponding author.

E-mail address: gcyras@vgtu.lt
} 
involvement of representatives of the $\mathrm{X}$ and $\mathrm{Y}$ generations in the activities of international e-commerce. In order to achieve the objective, the following objectives were set:- to analyze and define the concept of e-commerce;- to analyze the existing factors for engagement in e-commerce activities and the factors contributing to the involvement; - on the basis of generational theory, to identify differences in the characteristics of the $\mathrm{X}$ and $\mathrm{Y}$ generations which determine the decision-making of purchases on a virtual platform; Methods used to achieve the work objective: analysis of scientific and methodological sources, structuring of information.

\section{The Concept and Concept of E-Commerce}

The traditional business world has been cardinally replaced by innovation in information and communication technologies. The 1990s opened the way for innovation that promotes globalization. E-commerce has experienced strong economic growth worldwide over the last decade. This has been influenced by developing information technologies, changing socio-economic environments and people personal development (Kabbaj, 2018). Each year at least 1 billion consumers in the world buy goods and services online. Statistics show that by 2021, this number of consumers can be expected to increase to 2.16 billion shoppers per year (Clement, 2019). Such a rapid growth leads to electronic commerce being widely studied by scientists and researchers. Most researchers (Angelina et al., 2019; Abdullah et al., 2019; and Shaw, 2014) in defining the term "electronic commerce" highlights different aspects, such as business model, business methodology, business information exchange. Researchers (Angelina, Hermawan, and Suroso, 2019) argue that electronic commerce is the use of the Internet for business purposes, often leading to the conclusion of commercial transactions between the organization and the consumer. According to Abdullah et al. (2019), electronic commerce can be defined as a modern business methodology for organizations, traders and consumers in order to reduce costs, while at the same time improving the quality of goods and services and increasing the speed of service provision. According to Shaw (2014), electronic commerce is the exchange of business information, the maintenance of business relations and the conduct of business operations over telecommunications networks. Emphasizing virtual space defines electronic commerce as a platform of unlimited opportunities that exists online, and physical business is defined as limited opportunities (Ward et al., 2016, see Annex II). Azam, 2012). E-commerce is the realization of the entire business process chain using telecommunications and information technologies to achieve business goals (Santos et al., 2017). Khurana (2015) defines electronic commerce as the use of computer, internet and software for the sale of a product. Also for sending a quote, order, invoice, and other data required by customers, suppliers or employees. Detailed electronic commerce is defined like (Bhat, 2016): Electronic commerce is the use of electronic communications and digital information processing technology in business operations to create, restructure and redefine value-creation relationships between organizations and between organizations and individuals. After analyzing the definitions provided by different scientists Table 1 presents the concepts of e-commerce that are found in scientific literature.

Concepts of e-commerce (composed by authors)

\begin{tabular}{|l|l|}
\hline \multicolumn{1}{|c|}{ Author } & \multicolumn{1}{c|}{ Electronic Commerce Concepts } \\
\hline Shaw (2014) & $\begin{array}{l}\text { Electronic commerce is the exchange of business information, business communication and } \\
\text { business operations through telecommunications networks. }\end{array}$ \\
\hline $\begin{array}{l}\text { Ward, Sipior and } \\
\text { Volonino (2016) }\end{array}$ & $\begin{array}{l}\text { E-commerce is defined as a platform of unlimited opportunities that exists online, and } \\
\text { physical business is defined as a limited opportunity. }\end{array}$ \\
\hline Bhat (2016) & $\begin{array}{l}\text { Electronic commerce is the use of electronic communications and digital information } \\
\text { processing technology in business operations to create, restructure and redefine value } \\
\text { creation relationships between organizations and also between organizations and individuals. }\end{array}$ \\
\hline Santos et al. (2017) & $\begin{array}{l}\text { E-commerce is the realization of the entire business process chain using telecommunications } \\
\text { and information technologies, thus achieving business goals. }\end{array}$ \\
\hline Khurana (2015) & $\begin{array}{l}\text { Electronic commerce means the use of computer, internet and software for the sale of the } \\
\text { product. Customers, vendors or employees required to send a quote, order, invoice, and } \\
\text { other data. }\end{array}$ \\
\hline $\begin{array}{l}\text { Abdullah et al. } \\
\text { (2019) }\end{array}$ & $\begin{array}{l}\text { Electronic commerce can be defined as a modern business methodology for organisations, } \\
\text { traders and consumers in order to reduce costs, while at the same time improving the quality } \\
\text { of goods and services and increasing the speed of service provision. }\end{array}$ \\
\hline $\begin{array}{l}\text { Angelina, } \\
\text { Hermawan and } \\
\text { Suroso (2019) }\end{array}$ & $\begin{array}{l}\text { This is the use of the Internet for business purposes, often leading to the conclusion of } \\
\text { commercial transactions between the organization and the consumer. }\end{array}$ \\
\hline
\end{tabular}


The analysis of these definitions suggests that e-commerce involves various business processes carried out online and implements the entire service supply chain. The article therefore refers to this definition: electronic commerce is a modern business model based on the use of the Internet and information technologies to enable business processes in the digital space.

The strong increase in e-commerce has changed established traditional business rules and opened up new opportunities for business development. Electronic commerce allows for a wide range of transactions that are made electronically between companies, consumers and public authorities (Santos et al., 2017). Table 2 presents the types of e-commerce by the possibility of transactions. On the basis of different types of trade relations between countries, electronic commerce can be divided into different models: B2B, B2C, C2B, C2C and mobile commerce (Bhalekar and Ingle, 2015).

- Business to Business (B2B) is an e-commerce model that involves electronic transactions between companies doing business and providing services to each other. This is often the case with manufacturers selling products to agents or wholesalers selling goods to retailers. Prices are often set based on the quantity ordered (Pratima et al., 2015).

- Business-to-Consumer (B2C) model applies to any business or organization that sells its services or products to consumers online (Shaw, 2014).

- Consumer-to-Business (C2B) is an e-commerce model in which consumers create a certain value (product) and business organizations use the created value (Dhana Lakshmi and Shayena, 2018). Author K.R. Lakshmi (2018) argues that this business model is similar to a reverse auction where the buyer has the opportunity to specify his desired price.

- Consumer-to-Consumer (C2C) model, the buyer and seller are not direct entrepreneurs, but sales transactions are carried out. In most cases, a third party participates in such commercial relations, as an example - an online auction (Babenko et al., 2019).

- Mobile commerce. This model of e-commerce became apparent when mobile data became available in almost every part of the world. Mobile phones, laptops, digital watches, or cars use a wireless network (Shaw, 2014). Software can automate and simplify sales and service processes (Babenko et al., 2019)

Table 2.

E-commerce models (Santos et al., 2017)

\begin{tabular}{|l|l|l|}
\hline \multicolumn{1}{|c|}{ Tag } & \multicolumn{1}{c|}{ Name } & \multicolumn{1}{c|}{ Description } \\
\hline B2B & Business to Business & Transaction between companies \\
\hline B2C / C2B & $\begin{array}{l}\text { Business-to-Consumer/ Consumer- } \\
\text { to-Business }\end{array}$ & $\begin{array}{l}\text { Transaction between company and end user / Transaction } \\
\text { between user creating value for business and company }\end{array}$ \\
\hline C2C & Consumer-to-Consumer & Transaction between consumers \\
\hline G2C / C2G & $\begin{array}{l}\text { Government-Consumer/ Consumer } \\
\text { - Government }\end{array}$ & $\begin{array}{l}\text { Transaction between government and population / } \\
\text { Transaction between individual and government }\end{array}$ \\
\hline B2G / G2B & $\begin{array}{l}\text { Business - Government/ } \\
\text { Government - Business }\end{array}$ & Transactions between business and government \\
\hline G2G & Government-to the Government & Transactions between public authorities \\
\hline
\end{tabular}

E-commerce enables an organization to reach a wider, international market with minimal investment (A. Y. Vadwala and M. S. Vadwala, 2017). According to A. Y. Vadwala and M. S. Vadwala (2017), an organization using an e-commerce business model is much easier to reach with a larger flow of customers worldwide. Another important advantage of e-commerce is that products and services are available $24 / 7$, with unlimited working hours increasing organizational profits (Franco and Regi, 2016). The e-commerce model helps business organizations reduce the costs associated with developing, organizing, and empowering various processes in paper resources by digitizing all of these processes (A. Y. Vadwala and M. S. Vadwala, 2017).

E-commerce as a business model is beneficial not only for business organizations but also for consumers themselves. Flexibility and efficiency are among the key aspects of this business model that deliver benefits to the consumer. Consumers can efficiently get any information they need about a product or service and they don't have to leave home to complete a business transaction (Yadiati and Meiryani, 2019). According to A. Y. Vadwala and M. S. Vadwala (2017), e-commerce gives the consumer the opportunity to choose and compare products and services, that increasing competition between organizations and as a result, consumers receive discounts, gift vouchers for products and services. 


\section{Research Methodology}

The study of this article focused on the success factors of e-commerce. For the purpose of this article, a literature analysis, an analysis of the success models of information systems, an analysis of the needs and behavior of users of different generations, and systematic literature data and research results are carried out. A conceptual model conceptual model for the success of e-commerce by identifying the factors that determine the involvement of different generations in the international e-commerce activities is formed, consisting of eleven different components: generational difference, quality of information, system quality, cybersecurity, functionality, quality of service, product quality, price relevance, trust, user satisfaction, net benefit.

The study is based on the following points:

- Literature analysis. A review of the literature was carried out to define the concept of e-commerce, to highlight its advantages, to review the needs and behavior of users of different generations during shopping, and also to disease the critical success factors in e-commerce presented in the literature.

- Analysis of the success factors of e-commerce. The analysis was carried out on the basis of the model of success of DirM information systems found in the literature, the technology acceptance model (TAM) based on the action theory model (TRA).

- Development of a conceptual model for the success of e-commerce by identifying the factors that determine the involvement of different generations in the international e-commerce activities (e-commerce success factors). The model (see Figure 5) is based on an improved D\&M information systems model. Based on the needs of different generations of users found in the literature, the essential component of the model - the generational difference - was singled out.

Most recent research relates to trust and consumer behavior. There is a lack of information in the literature on the needs of different generations of users. Therefore, this study expands the scope of research on the success factors of e-commerce.

\section{The Success Factors for E-commerce}

Electronic commerce is evidence of the economic benefits of information and communication technologies. The use of information systems technologies supports economic growth and development, increases commercial efficiency and facilitates cooperation between countries (Choshin and Ghaffari, 2017). William DeLone ir Ephraim McLean (D\&M) the success model of information systems was designed to identify the main factors determining the success of IS (Roky and Meriouh, 2015). These researchers analyzed and integrated previous empirical efficacy studies of IS and developed a new model of IS success to summarize (Wang et al., 2019). D\&M IS the success model (see Figure 1) presents six key factors and their interrelationships: system quality, information quality, system usage, user satisfaction, individual impact, organizational impact. The quality of the system and the quality of information influence the use of the system, which determines user satisfaction, activity and organizational performance (Wang et al., 2019).

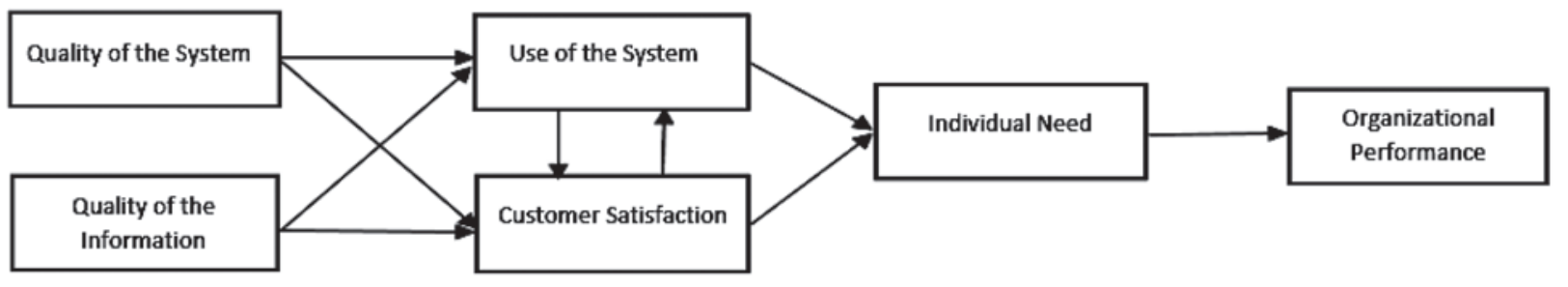

Fig. 1. D\&M IS success model (DeLone ir McLean, 2016).

An improved DeLone and McLean IS success model (see Figure 2) has been applied to e-commerce projects (Dasuki, 2018). Six success factors were selected based on user needs: information quality, system quality, service quality, benefit perception, user satisfaction, IS use / intention to use (Wang et al., 2019). The results of the studies that used an improved D\&M IS success model were not the same. Applying this model to an online e-commerce platform, it was found that system quality and information quality were key indicators determining consumer satisfaction (Dasuki, 2018). Meanwhile, Jagannathan et al. (2018) observed that the success of the online banking platform was not influenced by the quality of the system, but the decisive factor for customer satisfaction was the quality of information and security. The different results suggest that the model can be flexibly adapted to different areas of e-commerce. 


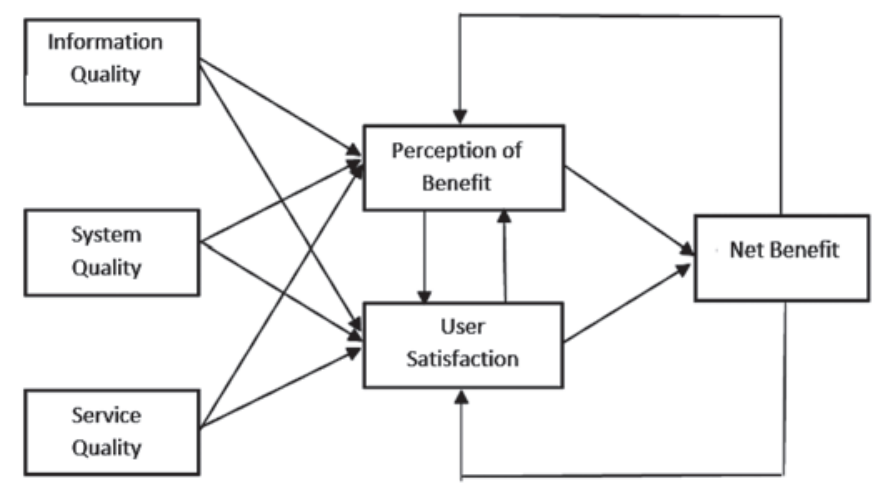

Fig 2. An improved D\&M IS success model (DeLone ir McLean, 2016).

When analyzing the critical factors that determine the success of e-commerce, it is important to pay attention not only to technological and environmental factors, but also to analyze the consumer and his needs, as well as behavior during shopping. As IS evolves, so do digital shopping platforms. Vendors offer more and more opportunities in the purchasing process and provide ever higher quality services and products (Pappas, 2018). For these reasons and continuous improvement, it is important to understand the reasons why customers choose to shop on electronic platforms and the factors that motivate them (Fedorko et al., 2018). In other words, analyzing consumer behavior and understanding their needs is a key aspect of e-commerce success.

E-commerce platforms aim to ensure that the consumer experiences only a positive experience and does not feel frustrated during the first visit using all features (Fedorko et al., 2018). The Technology Acceptance Model (TAM) is widely used to study consumer behavior in the IS environment. This model (see Figure 3) defines various factors related to the adoption of new technologies and the desire to improve in the field of technology, in relation to consumers. Attitudes towards consumption determine consumers 'willingness to use a particular technology and the simplicity of the technology (Guzzo et al., 2016). The TAM model stems from external consumer factors related to individual beliefs and personal attitudes (Dakduk et al., 2017). The consumer is aware of the likelihood that the use of new technologies will help to improve the quality of shopping and perform all functions faster and easier. But at the same time, the user seeks to make all new features and technologies easy to understand (Dakduk et al., 2017).

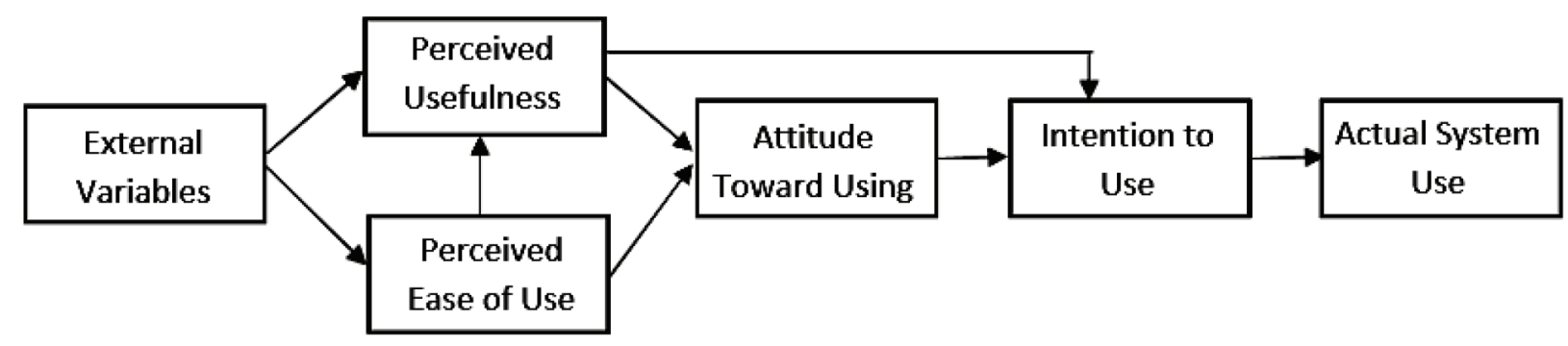

Fig. 3. The Technology Acceptance Model TAM (Dakduk et al., 2017).

The Theroy of Reasoned Action (TRA) model is often used to analyze user behavior. This model (see Figure 4) is used to understand and measure the relationship between a user's personal attitudes, intentions and behaviors. TRA theory states that people easily make simple decisions using information that is easily and quickly available to them (Solangi et al., 2018).

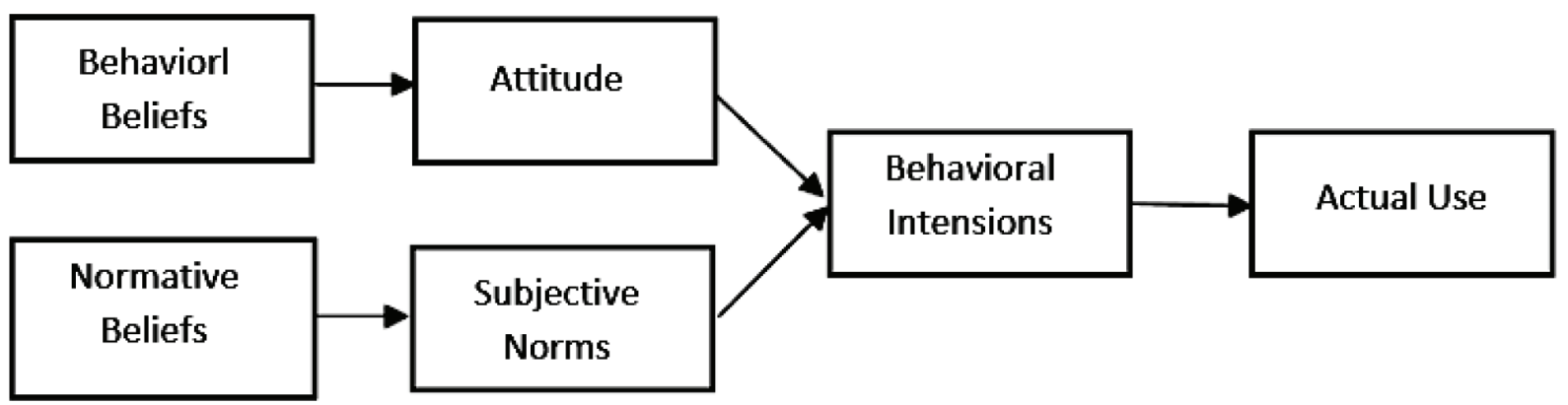

Fig. 4. Theroy of Reasoned Action (TRA) model (Solangi et al., 2018). 
TAM ir TRA models are interrelated. There is a link between consumer confidence in the usefulness of technology and the intention to use technology. Two main factors emerge from this: perceived usefulness and perceived ease of use. All of this determines the use of a particular technology or system (Ramadiani et al., 2017).

Analyzing the success factors of e-commerce, various classifications can be found in the literature to group success factors into certain categories. According to Choshin and Ghaffari (2017), in order to successfully develop e-commerce projects, it is important to take into account primary factors such as: detailed business model, optimal use of available resources, and analysis of customer needs. The literature contains classifications of success factors provided by various authors. The most important success factors in e-commerce are directly dependent on IS technologies and the Internet is divided into the following categories (Choshin ir Ghaffari, 2017, žr. Dyerson et al., 2009):

- Qualification factors: manager's knowledge and experience, employee competence, customer awareness;

- Environmental factors: state laws, market breadth, choice of producers and suppliers;

- Human factors: availability and use of internal resources, demand for specialists;

- Human factors: availability and use of internal resources, demand for specialists.

- Research can also find an alternative classification of success factors for e-commerce (Choshin ir Ghaffari, 2017, žr. Ramanathan et al., 2012):

- Performance factors: customer satisfaction, process improvement and competitiveness;

- Marketing factors: online advertising, customer awareness and brand awareness;

- Technological factors: continuous improvement of quality and communication, online security, simple website design, detailed and quickly accessible information.

The methods of "measuring" the success of e-commerce are different from the methods of analyzing the success of the physical services market. Therefore, the quality of e-services is defined as the overall customer satisfaction with the quality of services in the virtual market (Varela et al., 2017). In the literature (Varela et al., 2017; see Kawasaki, 2004), the prevailing view is that website design / platform design, performance, reliability (security and privacy policy), and speed of customer service are determinants of customer loyalty. It was also found that factors (eg: smooth operation of IS programs, employees who know their profession, security in virtual space, effective communication in the network) related to the efficient use of information systems ensure the successful implementation of e-commerce project ( Choshin ir Ghaffari, 2017, žr. Fathian et al., 2008).

\section{Factors Determining the Differences Between the $X$ and $Y$ Generations}

In the literature analyzing the success factors of e-commerce, it can be observed that the relationships between environmental factors, technological factors and consumer needs are most often examined (Varela et al., 2017; Kawasaki, 2004; Choshin and Ghaffari, 2017; Wang et al., 2019; Dasuki, 2018 ; DeLone and McLean, 2016; Fedorko et al., 2018; Dakduk et al., 2017). There is not enough information in the literature to relate to the behavior and choices of consumers of different ages (different generations) when using e-commerce platforms. Due to age changes, older consumer decision-making processes and habits differ from younger users (Benjamin, Fang, Wen, and George, 2016). The theory of information processing explains that older consumers are less likely to search for additional data about the product or deal with problems based on the latest technologies (Benjamin et al., 2016). Their purchase is based on simplicity. Shoppers with more online shopping experience are able to make decisions with less information. This shows that mature consumers can use a simpler set of criteria when making purchasing decisions, but at the same time have less confidence in e-commerce services. In contrast, younger buyers feel easier and boldly use all the search options before making a decision to compare similar products in the market.

Different times of birth naturally divide people into separate social groups. The literature argues that people who are linked by a common period of birth and then the prevailing historical space give them a collective personality (RamírezCorrea et al., 2019). This concept, the collective personality, is used in marketing to identify different generations. They have been classified since 1900. For periods of 20 years. Generations are divided into: G1, Silent Generation, Baby Boom Generation, Generation X, Generation Y, and Generation Z since 2003.(Ramírez-Correa et al., 2019).

Generations $X$ are consumers born before the late 1980s. The literature notes that this generation is also referred to as the "fear generation" because they have experienced economic crises, nuclear wars, and job shortages (Chaney et al., 2017). These factors may explain Generation X's skeptical marketing incentives, making it more difficult to manipulate and persuade consumers in this segment (Chaney et al., 2017). Generation Y has grown up accompanied by the Internet and new technologies. In the era of information development and the rise of social networks, the daily lives of these users have become inseparable from the Internet, and their actions are greatly influenced by network culture. (Lee ir Lee, 2020).

According to Lee and Lee (2020), Generation Y consumers are characterized by strong independence, personalized concepts of consumption, are no longer affected by a hierarchy of fear and power, and share and disseminate information about products and new brands. 
In researching the success factors of e-commerce, it was observed that the differences and special features of the $\mathrm{X}$ and $\mathrm{Y}$ generations are characteristic of a certain generation and may be related to the consumer's decision to buy a product or service (Ramírez-Correa et al., 2019). Ross-Cortes et al. (2016) show that when using X-commerce agents on e-commerce platforms, the final decision is influenced by the opinion expressed by other users, and for Generation Y individuals it is not important. They trust their decisions and do not want to be dependent on the opinions of others. An analysis of the literature also reveals a predominant term: intergenerational marketing. This type of marketing consists of a supply of goods or services tailored to a specific generation (Chaney et al., 2017). According to Chaney et al., (2017) using an intergenerational marketing strategy, e-commerce platforms focus on products that are directly related to the chosen generation, in an effort to reflect the values of the generation. But this reflects only a narrow part of the supply and cannot guarantee a mass purchase.

There is a very strong connection between different generations and information and communication technologies. The interactions of each generation with the media and the Internet influence e-commerce strategies and outcomes (Chaney et al., 2017; Wang et al., 2008). Currently, online and mobile advertising seem to be the most promising type of advertising, but research shows that the recognition and acceptance of this type of advertising varies from generation to generation (Chu and Sung, 2015). The relationship with television is also unequal for different generations. E-commerce platforms definitely need to use social networks when trying to reach the consumer through television, as both the $\mathrm{Y}$ and $\mathrm{Z}$ generations give priority to social network advertising over that of television (Chaney et al., 2017). Generation Y currently accounts for the largest share of purchasing power online, making this generation often the most important customer on e-commerce platforms (Chakraborty and Balakrishnan, 2017). But on the other hand, Generation X agents are those consumers who currently generate the most revenue and have the highest costs, but Generation X agents often choose physical stores for shopping (Wang et al., 2019). It is for this reason that it is worth emphasizing both the $\mathrm{X}$ and $\mathrm{Z}$ generations. E-commerce platforms should improve their business models as well as digital platforms to meet the needs of both generations.

Based on the literature review above, many factors for the success of e-commerce have been identified. Different factors were discuss by identifying them individually or in groups from certain perspectives (Varela et al., 2017; Kawasaki, 2004; Choshin ir Ghaffari, 2017; Wang et al., 2019; Dasuki, 2018; DeLone ir McLean, 2016; Fedorko et al., 2018; Dakduk et al., 2017. E-commerce is a complex e-business process that requires knowledge of various disciplines. It is therefore clear that an advanced framework needs to be developed that integrates the critical success factors of the various interfaces. Therefore, based on the improved DeLone and McLean e-commerce success model, a new conceptual e-commerce success model was developed (see Figure 5). This model integrates a generational difference factor that must be taken into account for successful e-commerce activities.

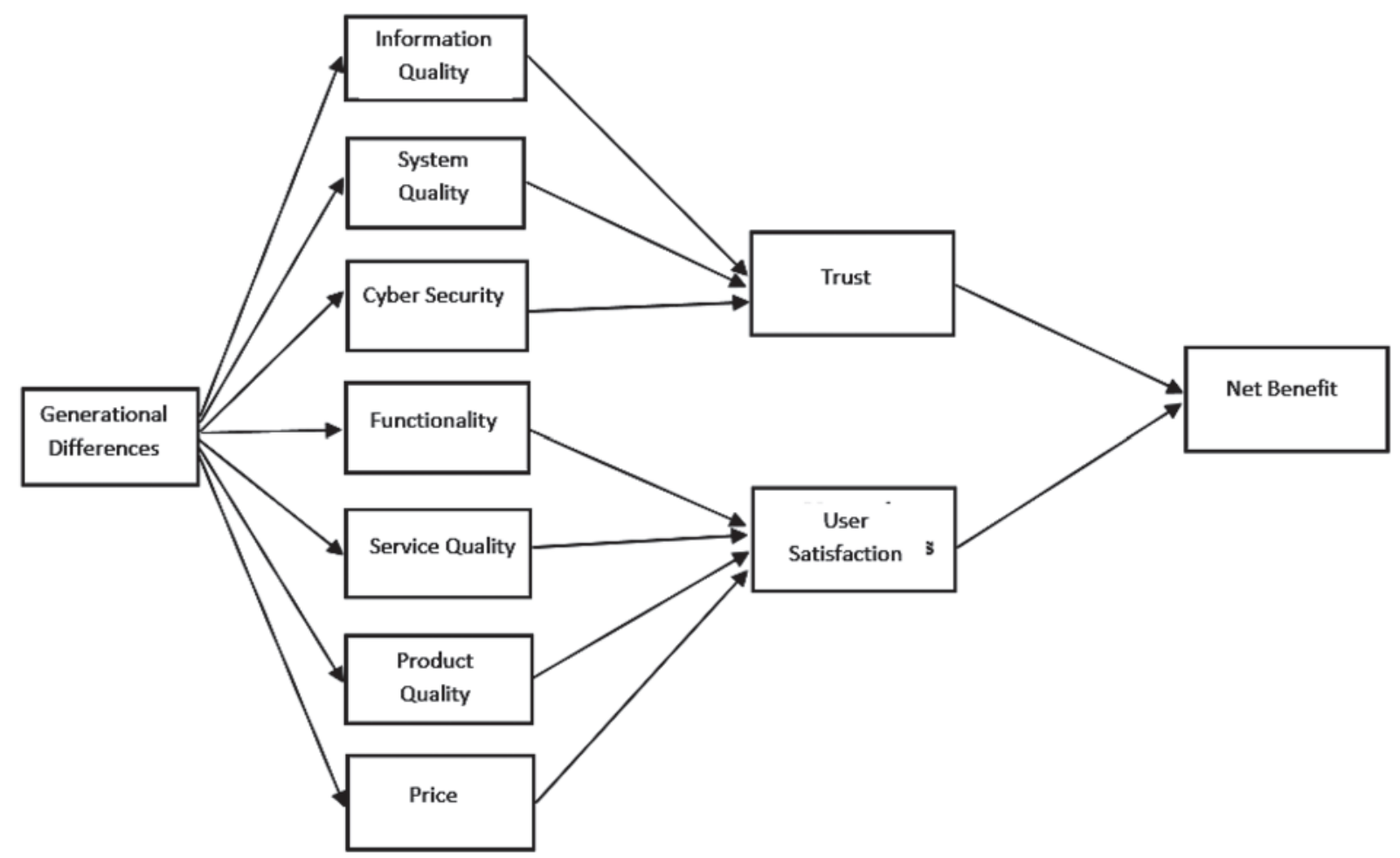

Fig. 5. Conceptual model of different generations users involvment into international e-commerce activities (compiled by the authors). 
A theoretical model of different generations users involvment into international e-commerce activities factors has been developed based on the D\&M information systems success model. The developed conceptual model covers eleven different factors (generational difference, information quality, system quality, cyber security, functionality, service quality, product quality, price adequacy, trust, customer satisfaction, net benefit) that determine the success of e-commerce. Factors were selected based on literature analysis and previous research. The difference between the generations is singled out as the dominant factor. It is noteworthy that generations $\mathrm{X}$ and $\mathrm{Y}$ currently generate the greatest purchasing power online, but as the literature suggests (Wang et al., 2019; Ramírez-Correa et al., 2019; Chakraborty and Balakrishnan, 2017), their needs for e-commerce platforms differ . For this reason, it is important to take into account the needs and characteristics of different generations of consumers in order to successfully develop e-commerce activities. It is noted that a limited amount of information is found in the literature related to the needs of different generations of users. Accurate identification of these needs requires further research through a consumer survey. This is the next intended line of research to build an effective model of e-commerce success factors.

\section{Conclusions}

After analyzing the sources of scientific and methodological literature, various definitions of e-commerce were found. It was found that when analyzing the definitions of e-commerce, some authors emphasize new technologies, the use of information and communication technologies to enable business processes, others - the benefits of using the platform of unlimited possibilities and the growth of business process chain efficiency. Meanwhile, according to the authors it is appropriate to define the term e-commerce as a modern business model based on the use of the Internet and information technology to enable business processes in the digital space. It is important to understand that the goal of an e-commerce platform is to enable business processes and reach the consumer in the most targeted way possible.

The analysis of the success factors of e-commerce identified that the main factors determining the success of e-commerce are: environmental factors, technological factors (online security) and customer satisfaction. Further analysis evaluated D\&M IS the success model and the TAM and TRA models, which are related to consumer behavior on digital platforms. The analysis of these models revealed that there is a certain correlation between consumer attitudes towards the efficiency of new technologies and the willingness to use them. Based on this relationship, an analysis of the characteristics, needs, and behaviors of consumers of different ages was initiated.

Based on the literature rewiev, the needs and behavior of different generations of users, it has been observed that older consumers tend to shop in physical stores, as their level of trust in digital platforms is much lower than younger consumers. Generation Y consumers have grown up in a technological era so they are more flexible and easier to make decisions than Generation $\mathrm{X}$ users. These factors are important for success in e-commerce.

After analyzing the literature and based on statistical data, it was found that the largest group of existing users consists of representatives of two different generations. Based on the literature, it has been found that the needs of different generations of users differ. Based on this analysis, a conceptual model for the success of e-commerce by identifying the factors that determine the involvement of different generations in the international e-commerce activities was developed that included the factor of generational difference as a factor determining success in e-commerce. In order to better determine the impact of the generational difference on the success of e-commerce, additional analysis will be carried out in a consumer survey, as this factor is not given enough attention in scientific sources.

\section{Literature}

1. Abdullah, L., Ramli, R., Bakodah, H. O., \& Othman, M. (2019). Developing a causal relationship among factors of e-commerce: A decision making approach. Journal of King Saud University - Computer and Information Sciences, (in Press), 1-8. https://doi.org/10.1016/j.jksuci.2019.01.002

2. Angelina, R. J., Hermawan, A., \& Suroso, A. I. (2019). Analyzing e-commerce success using DeLone and McLean model. Journal of Information Systems Engineering and Business Intelligence, 5(2), 156-162. https:// doi.org/10.20473/jisebi.5.2.156-162

3. Azam, R. (2012). Global taxation of cross border e-commerce income. Virginia Tax Review, 31, 639.

4. Babenko, V., Kulczyk, Z., Perevozova, I., Syniavska, O., \& Davydova, O. (2019). Factors of development of international e-commerce in the context of globalization. CEUR Workshop Proceedings, 2422, 345-356.

5. Bhalekar, P., Ingle, S., \& Pathak, K. (2015) The study of e-commerce. Asian Journal of Computer Science and Information Technology, 4(3), 25-27.

6. Chakraborty, T., \& Balakrishnan, J. (2017). Exploratory tendencies in consumer behaviour in online buying across gen X, gen Y and baby boomers. International Journal of Value Chain Management, 8(2), $135-150$. https://doi.org/10.1504/IJVCM.2017.085483 
7. Chaney, D., Touzani, M., \& Ben Slimane, K. (2017). Marketing to the (new) generations: summary and perspectives. Journal of Strategic Marketing, 25(3), 179-189. https://doi.org/10.1080/0965254X.2017.1291173

8. Choshin, M., \& Ghaffari, A. (2017). An investigation of the impact of effective factors on the success of e-commerce in small- and medium-sized companies. Computers in Human Behavior, 66, 67-74. https://doi. org/10.1016/j.chb.2016.09.026

9. Clement, J. (2019). Topic: E-commerce worldwide. https://www.statista.com/topics/871/online-shopping/

10. Cristofaro, M. (2019). E-business evolution: An analysis of mobile applications' business models. Technology Analysis and Strategic Management, 1-16. https://doi.org/10.1080/09537325.2019.1634804

11. Dakduk, S., ter Horst, E., Santalla, Z., Molina, G., \& Malavé, J. (2017). Customer behavior in electronic commerce: A bayesian approach. Journal of Theoretical and Applied Electronic Commerce Research, 12(2), 1-20. https://doi.org/10.4067/S0718-18762017000200002

12. Dasuki, S. I. (2018). Assessing e-learning systems success in Nigeria: An aplication of the Delone and Mclean Information Systems Success Model. Thecnology Education: Research, 17, 182-202. https://doi. org/10.28945/4077

13. DeLone, W. H., \& McLean, E. R. (2003). The DeLone and McLean model of information systems success: A ten-year update. Journal of Management Information Systems, 19(4), 9-30. https://doi.org/10.1080/07421222.2 003.11045748

14. DeLone, W. H., \& McLean, E. R. (2016). Information systems success measurement. Foundations and Trends ${ }^{\circledR}$ in Information Systems, 2(1), 1-116. https://doi.org/10.1561/2900000005

15. Dhana Lakshmi, K. R., \& Shayena, S. (2018). E-commerce and it's impact on markets and retailers. International Journal of Research and Analytical Reviews (IJRAR), 5(3), 234-239. http://www.ijrar.org

16. Dyerson, R., Harindranath, G., \& Barnes, D. (2009). National Survey of SME's use of IT in four secters. Electronic Journal of Information Systems Evaluations, 12, 39-50.

17. Fang, J., Wen, C., George, B., \& Prybutok, V. R. (2016). Consumer heterogeneity, perceived value, and repurchase decision-making in online shopping: The role of gender, age, and shopping motives. Journal of Electronic Commerce Research, 17(2), 116-131. https://pdfs.semanticscholar.org/0bca/6352595935287ebaa523e96776d6b96e80cf.pdf

18. Fathian, M., Akhavana, P., \& Hoorali, M. (2008). E-readiness assessment of non-profit ICT SMEs in developing countyr: The case od Iran. Technovation, 28(9), 578-590. https://doi.org/10.1016/j.technovation.2008.02.002

19. Fedorko, I., Bacik, R., \& Gavurova, B. (2018). Technology acceptance model in e-commerce segment. Management and Marketing, 13(4), 1242-1256. https://doi.org/10.2478/mmcks-2018-0034

20. Franco, D. C. E., \& Regi., S. B. (2016). Advantages and challenges of e-commerce customers and businesses: In Indian perspective. International Journal of Research - Granthaalayah, 4(3), 7-13. http://granthaalayah.com/ Articles/Vol4Iss3/02_IJRG16_SE03_02.pdf

21. Guzzo, T., Ferri, F., \& Grifoni, P. (2016). A model of e-commerce adoption (MOCA): Consumer's perceptions and behaviours. Behaviour and Information Technology, 35(3), 196-209. https://doi.org/10.1080/014492 9X.2015.1132770

22. Kabbaj, M. W. (2018). The major factors that contribute to e-commerce growth in the U.S and China: Analyses and adoption by Morocco. https://digitalcommons.salemstate.edu/honors_theses/204/

23. Kawasaki, G. (2004). The Art of the start: The time-tested, battle-hardened guide for anyone starting anything. https://www.amazon.com/Art-Start-Time-Tested-Battle-Hardened-Starting/dp/1591840562

24. Kinda, T. (2019). E-commerce as a potential new engine for growth in Asia. https://doi. org/10.5089/9781498317467.001

25. Lee, C.-H. (2020). Generation difference of post-90s in the context of the rise of social commerce. Advances in Management \& Applied Economics, 10(1), 15-33

26. Lin,Y.,Luo, J.,Cai,S.,Ma,S.,Rong, K.,2016. Exploring the service quality in the e-commerce centext: a triadic view.Ind.Manage.Data Syst. 116(3), 388-415

27. Pappas, I. O. (2018). “User experience in personalized online shopping: a fuzzy-set analysis”, European Journal of Marketing-

28. Prakapienė, D., Prakapas, R., Dudzevičiūtė, G. 2018. Influence of Social Media on National Security: Lithuanian Academic Youth Experience. In Challenges to National Defence in Contemporary Geopolitical Situacion (CNDCGS'2018) Proceedings, International Conference and Live Firing Show'2018, April 25-27, Vilnius, General Jonas Žemaitis Military Academy of Lithuania.

29. Mehra, J., \& Khurana, A. (2015). E-commerce: Opportunities and challenges. The International Journal of Business \& Management, 3(1), 182-186.

30. Miniwatss marketing group. (2019). World Internet Users Statistics and 2019 World Population Stats. https:// www.internetworldstats.com/stats.htm 
31. Jagannathan, V., Balasubramanian, S., \& Natarajan, T. (2018). An extension to the Delone and Mclean information systems success model and validation in the internet banking context. In M. Khosrow-Puour (Ed.), Encyclopedia of Information Science and Technology (4th ed.), pp. 49-60.

32. Ramadiani, Azainil, Haryaka, U., Agus, F., \& Kridalaksana, A. H. (2017). User satisfaction model for e-learning using smartphone. Procedia Computer Science, 116, 373-380. https://doi.org/10.1016/j.procs.2017.10.070

33. Ramanathan, R., Ramanathan, U., \& Hsia, H.-L. (2012). The impact of e-commerce on Taiwanese SMEs: Marketing and operations effects. International Journal of Production Economics, 140(2), 934-943. https://doi. org/10.1016/j.ijpe.2012.07.017

34. Ramírez-Correa, P. E., Grandón, E. E., \& Arenas-Gaitán, J. (2019). Assessing differences in customers' personal disposition to e-commerce. Industrial Management and Data Systems, 119(4), 792-820. https://doi. org/10.1108/IMDS-07-2018-0280

35. Roky, H., \& Meriouh, Y. Al. (2015). Evaluation by users of an industrial information system (XPPS) based on the DeLone and McLean model for IS success. Procedia Economics and Finance, 26(0), 903-913. https://doi. org/10.1016/S2212-5671(15)00903-X

36. Ross-Cortes, E., Ramírez-Correa, P. and Rondan-Cataluña, F.J. (2016), "Estudio exploratorio sobre las diferencias generacionales en la transmisión y recepción de opiniones en línea por parte de los compradores en el contexto de los servicios de redes sociales", Revista ESPACIOS, Vol. 37 No. 17, p. 12

37. Rigby, C. (2019). UK business online sales grow at fastest rate on record. https://internetretailing.net/

38. Santos, V. F. dos, Sabino, L. R., Morais, G. M., \& Goncalves, C. A. (2017). E-commerce: A short history followup on possible trends. International Journal of Business Administration, 8(7), 130. https://doi.org/10.5430/ijba. $\mathrm{v} 8 \mathrm{n} 7 \mathrm{p} 130$

39. Shaw, M. J. (2014). Electronic commerce: State of the art. Handbook on Electronic Commerce, 4(4), 3-24. https://doi.org/10.1007/978-3-642-58327-8_1

40. Solangi, Y. A., Solangi, Z., Raza, A., Madihah Bt, M. B. S., bin Hamzah, M. S., \& Shah, A. (2018). Social commerce in e-business of Pakistan: Opportunities, challenges and solutions. In International Conference on Information and Communication Technology for the Muslim World (ICT4M 2018), Kuala Lumpur, pp. 126-131. https://doi.org/10.1109/ICT4M.2018.00032

41. Vadwala, A. Y., \& Vadwala, M. S. (2017). E-commerce: Merits and demerits a review paper. International Journal of Trend in Scientific Research and Development, 1(4). https://doi.org/10.31142/ijtsrd106

42. Varela, M. L. R., Araújo, A. F., Vieira, G. G., Manupati, V. K., \& Manoj, K. (2017). Integrated framework based on critical success factors for e-commerce. Journal of Information Systems Engineering \& Management, 2(1), 1-9. https://doi.org/10.20897/jisem.201704

43. Wang, Y.S., 2008. Assessing e-commerce systems success: a respecification and validation of the DeLone and McLean model of IS success. Inform. Syst. J. 18 (5), 529-557

44. Wang, Y. S., Tseng, T. H., Wang, W. T., Shih, Y. W., \& Chan, P. Y. (2019). Developing and validating a mobile catering app success model. International Journal of Hospitality Management, 77, 19-30. https://doi. org/10.1016/j.ijhm.2018.06.002

45. Ward, B. T., Sipior, J. C., \& Volonino, L. (2016). Internet jurisdiction for e-commerce. Journal of Internet Commerce, 15(1), 1-17. https://doi.org/10.1080/15332861.2015.1109988

46. Yadiati, W., \& Meiryani. (2019). The role of information technology in E-Commerce. International Journal of Scientific and Technology Research, 8(1), 173-176. 